\title{
Pengembangan Wisata Budaya Di Desa Wisata Tapak Tilas Sultan Agung Dan Desa Wisata Songgo Langit
}

\author{
Tanto Lailam ${ }^{1}$, Awang Daru Murti ${ }^{2}$, Ani Yunita $^{3}$ \\ ${ }^{1}$ Fakultas Hukum Universitas Muhammadiyah Yogyakarta. Jalan Brawijaya, Tamantirto, \\ Kasihan, Bantul DIY. E-mail: tanto.tatanegara@gmail.com \\ ${ }^{2}$ Fakultas Sosial dan Politik Universitas Muhammadiyah Yogyakarta. Jalan Brawijaya, \\ Tamantirto, Kasihan, Bantul DIY. E-mail: awang.darumurti@yahoo.co.id \\ ${ }^{3}$ Fakultas Hukum Universitas Muhammadiyah Yogyakarta. Jalan Brawijaya, Tamantirto, \\ Kasihan, Bantul DIY. Email: aniyunita@umy.ac.id
}

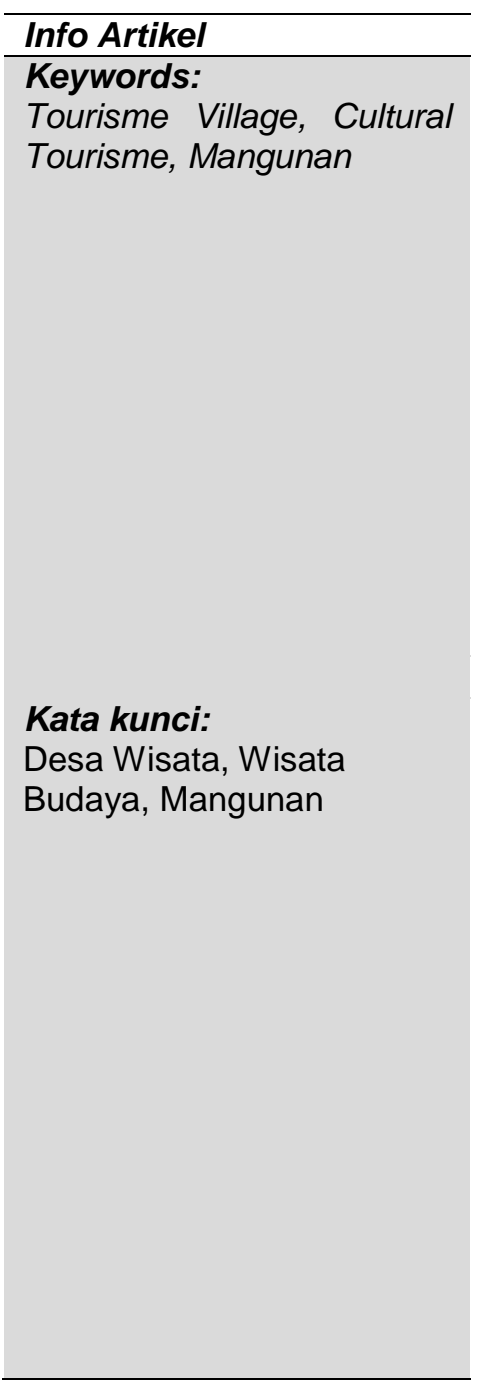

\begin{abstract}
The development of cultural tourism in the Tapak Tilas Sultan Agung Tourism Village and Songgo Langit Tourism Village is part of the Program Pengembangan Desa Mitra (PPDM) which focused on the Mangunan Village Program as a Competitive and Cultured Superior Tourism Village. The purpose of this program is to make partners as a centre model for community economic growth and sustainable community welfare through the potential of a tourism village that is integrated with culture. The Development programs carried out include legalizing associations in the form of art galleries. To legalize the Sanggar Lestari Budoyo and the Sanggar Ngesti Budoyo, a notary deed was made so that the activity has validity and is protected by regulations. Another program is training in innovation in the development of cultural arts and cultural tourism packaging.
\end{abstract}

\begin{abstract}
Abstrak
Pengembangan wisata budaya di Desa Wisata Tapak Tilas Sultan Agung dan Desa Wisata Songgo Langit ini merupakan bagian dari Program Pengembangan Desa Mitra (PPDM) ini memfokuskan pada program Desa Mangunan Sebagai Wisata Desa Unggulan Yang Kompetitif dan Berbudaya. Tujuan program ini adalah menjadikan mitra sebagai model pusat pertumbuhan ekonomi kerakyatan dan kesejahteraan masyarakat berkelanjutan melalui potensi desa wisata yang dipadukan dengan budaya. Program pengembangan yang dilakukan, meliputi: legalisasi perkumpulan dalam bentuk sanggar seni. Untuk melakukan legalisasi Sanggar Lestari Budaya dan Sanggar Ngesti Budoyo dibuatlah akta notaris agar dalam beraktivitas memiliki keabsahan dan dilindungi oleh Peraturan Perundang-undangan yang berlaku. Program lainnya adalah pelatihan inovasi pengembangan seni budaya, pemaketan wisata budaya.
\end{abstract}

\section{PENDAHULUAN}

Desa Mangunan merupakan sebuah desa yang terletak Kecamatan Dlingo, Kabupaten Bantul. Berjarak sekitar $35 \mathrm{~km}$ dari pusat Kota Yogyakarta. Lokasi yang mulai dikembangkan sebagai kawasan wisata pada Tahun 2003 di atas seluas 23,3415 hektar pada ketinggian 150-200m di atas permukaan laut. Titik ketinggian yang membuat kawasan ini memiliki alam yang indah dan udara yang sejuk serta pemandangan pegunungan seribu yang menyajikan berbagai ribuan keindahan alam. Desa Mangunan ini memiliki beberapa keunggulan potensi dan keunikan daya tarik pariwisata, baik daya tarik wisata alam, daya tarik wisata religi dan budaya, daya tarik wisata buatan manusia, dan daya tarik wisata kerajinan dan wisata kuliner. 
Menurut Gubernur DIY Sri Sultan Hamengkubuwono X bahwa Kecamatan Dlingo (termasuk desa Mangunan) akan dikembangkan sebagai model pusat pertumbuhan ekonomi dan kesejahteraan masyarakat melalui potensi desa wisata yang dipadukan dengan budaya, agar pertumbuhan desa wisata bisa lebih tertata dengan baik pengelolaannya dengan memadukan unsur budaya dan lebih terintegrasi sehingga bisa meningkatkan kesejahteraan masyarakat luas.

Pengembangan tersebut disambut baik oleh pemeritah desa dan masyarakat, dengan berbagai keunikan dan keunggulan baik wisata alam maupun budaya meneguhkan komitmen untuk membuat desa wisata. Desa wisata adalah suatu wilayah pedesaan yang menawarkan keaslian baik dari segi sosial budaya, adat istiadat, keseharian, arsitektur tradisional, struktur tata ruang desa yang disajikan dalam suatu bentuk integrasi komponen pariwisata antara lain seperti atraksi, akomodasi dan fasilitas pendukung.

Dalam arti bahwa desa wisata merupakan suatu bentuk integrasi antara atraksi, akomodasi dan fasilitas pendukung yang disajikan dalam suatu struktur kehidupan masyarakat yang menyatu dengan tata cara dan tradisi yang berlaku (nilai-nilai kearifan lokal). Esensi desa wisata yang mengedepankan suasana keaslian suatu desa memerlukan suatu pemahaman tentang karakter dan unsur-unsur yang ada di dalam desa, termasuk didalamnya unsur pengetahuan dan kemampuan lokal serta kearifan lokal yang dimiliki oleh masyarakat (Eko Murdiyanto, 2011: 91).

Desa wisata di Mangunan tersebut dikelola secara mandiri berbasis masyarakat dari pendirian hingga saat ini, dengan modal dan pengelolaan dari masyarakat di desa wisata tersebut. Desa wisata ini merupakan salah satu bentuk penerapan pembangunan pariwisata berbasis masyarakat, masyarakat lokal berperan penting dalam pengembangan desa wisata karena sumber daya dan keunikan tradisi dan budaya yang melekat pada komunitas tersebut merupakan unsur penggerak utama kegiatan desa wisata. Di lain pihak, komunitas lokal yang tumbuh dan hidup berdampingan dengan suatu objek wisata menjadi bagian dari sistem ekologi yang saling kait mengait. Keberhasilan pengembangan desa wisata tergantung pada tingkat penerimaan dan dukungan masyarakat lokal (Made Heny, dkk, 2013: 132).

Beberapa desa wisata yang berada di Desa Mangunan yang dikelola masyarakat dan menjadi mitra dalam program PPDM ini, meliputi: Desa Wisata Songgo Langit; dan Desa Wisata Tapak Tilas Sultan Agung. Desa Wisata Songgo Langit berada di Dusun Sukorame, Mangunan. Sementara Desa Wisata Tapak Tilas Sultan Agung berada di Dusun Cempluk, Desa Mangunan. Potensi Desa Wisata Tapak Tilas Sultan Agung tergabung kedalam Sanggar Lestari Budaya, yang meliputi: Sendra Tari, Karawitan Ngudiwiromo, Kethoprak Mudo Budoyo, Seni Tari Lestari Budaya, Jathilan Mudo Esthi Tomo, Wayang Kulit Ngesti Budoyo, Gejok lesung Laras budoyo, Sholawat Nabi, Hadroh Al Ittihad.

Sementara, wisata Budaya di Desa Wisata Songgo Langit yang menarik dan unggul adalah kesenian yang tergabung dalam Sanggar Ngesti Budoyo, yang didalamnya terdapat Kesenian Wayang Wong, Rasulan, Wiwitan, Sholawat Maulid Nabi, dan lainnya. Wayang Wong ini merupakan suatu pertunjukan teater yang di lakukan sekelompok orang yang menceritakan cerita pewayangan. Wayang wong merupakan suatu perpaduan seni drama, tari dan cerita pewayangan yang di kemas menjadi satu dalam suatu pertunjukan wayang wong. Dalam pementasan wayang wong modern biasanya menggunakan visualisasi panggung yang sesuai dengan cerita agar cerita yang yang di sampailkan dapat mudah tersampaikan kepada para penonton. Potensi yang sangat banyak tersebut perlu dikembangkan agar mampu melakukan inovasi budaya kekinian dan dapat diterima masyarakat luas.

\section{BAHAN DAN METODE PELAKSANAAN}

Pemberdayaan masyarakat adalah suatu proses dimana masyarakat, terutama mereka yang miskin sumberdaya, kaum perempuan dan kelompok yang terabaikan lainnya di lokasi dusun - desa 
wisata didukung agar mampu meningkatkan kesejahteraannya secara mandiri. Dalam proses ini, lembaga berperan sebagai fasilitator yang mendampingi proses pemberdayaan masyarakat, yang pada prinsipnya masyarakatlah yang menjadi actor dan penentu pembangunan desa wisata, baik pembangunan atraksi- akomodasi dan fasilitasi desa wisata, kelembagaan pariwisata, promosi dan komunikasi pemasaran, serta usaha berbasis masyarakat.

Usulan-usulan masyarakat merupakan dasar bagi program pembangunan desa wisata. Aspek penting dalam suatu program perberdayaan masyarakat adalah: program yang disusun sendiri oleh masyarakat, menjawab kebutuhan dasar masyarakat, mendukung keterlibatan, dibangun dari sumberdaya lokal, penguatan nilai-nilai budaya setempat, memperhatikan dampak lingkungan, tidak menciptakan ketergantung-an, berbagai pihak terkait terlibat, serta berkelanjutan.

Beberapa metode yang digunakan dalam pemberdayaan masyarakat ini:

1. Survei dan wawancara. Survei dan wawancara ini dilakukan untuk melihat perkembangan potensi wisata yang telah dikembangkan sebelumnya, sekaligus melihat potensi inovasi yang akan dikembangkan oleh pengelola desa wisata.

2. Pelatihan. Metode pelatihan dilakukan untuk mengurangi persoalan ketiadaan regulasi dan pedoman tata kelola, pengetahuan dan kekurangpahaman pengelola desa wisata (sumber daya manusia/ mitra) terhadap manajemen tata kelola, SDM, dan pemasaran - komunikasi pariwisata. Program-program pelatihan dalam pengabdian masyarakat dikembangkan dengan metode yang lebih sederhana, yaitu dengan menyelenggarakan sarasehan dan diskusi santai/ informal sehingga masyarakat tidak terlalu berat dalam menerima materi-materi pelatihan. Fasilitasi. Fasilitasi berkaitan dengan pemberian atau mempermudah akses terhadap upaya Desa Wisata untuk melakukan legalisasi kelembagaan.

Selain metode di atas, mitra juga dapat melakukan konsultasi dengan tim pengabdian atau ahliahli tertentu dengan difasilitasi oleh tim pengabdi.

\section{HASIL DAN DISKUSI}

\section{A. Potensi Wisata Budaya}

Kebudayaan adalah segala sesuatu yang berkaitan dengan cipta, rasa, karsa, dan hasil karya masyarakat. Kebudayaan merupakan investasi untuk membangun masa depan dan peradaban yang lebih maju, dalam Undang-undang Pemajuan Kebudayaan yang masuk lingkup objek kebudayaan meliputi: tradisi lisan, manuskrip, adat istiadat, ritus, pengetahuan tradisional, teknologi tradisional, seni, bahasa, permainan rakyat, dan olahraga tradisional. Kebudayaan ini menjadi daya tarik wisata, dalam Pasal 6 Undang-undang No.10 tahun 2009 tentangKepariwisataan, menyebutkan bahwa pembangunan kepariwisataan dilakukan dengan memperhatikan keanekaragaman, keunikan, dan kekhasan budaya dan alam, serta kebutuhan manusia untuk berwisata.

Perpaduan wisata dengan budaya melahirkan daya tarik wisata budaya sebagai segala sesuatu yang memiliki keunikan, keindahan, dan nilai yang berdimensi budaya yang menjadi sasaran atau tujuan kunjungan wisatawan. Dapat dipahami pula bahwa wisata budaya merupakan kegiatan perjalanan yang dilakukan oleh seseorang atau kelompok dengan mengunjungi tempat tertentu untuk tujuan rekreasi, pengembangan pribadi, atau mempelajari daya tarik budaya dengan memanfaatkan potensi budaya dari tempat yang dikunjungi tersebut.

Menurut Nafila (2013) bahwa pariwisata budaya adalah salah satu jenis pariwisata yang menjadikan budaya sebagai daya tarik utama. Dimana di dalam pariwisata budaya ini wisatawan akan diapndu untuk disamping mengenali sekaligus memahami budaya dan kearifan pada komunitas lokal tersebut. Disamping itu, pengunjung akan dimanjakan dengan pemandangan, tempat-tempat bersejarah sekaligus museum, representasi nilai dan sistem hidup masyarakat lokal, seni (baik seni pertunjukan atau pun seni lainnya), serta kuliner khas dari masyarakat asli atau masyarakat lokal yang bersangkutan. Goeldner mengemukakan bahwa pariwisata budaya mencakup semua aspek dalam perjalanan untuk saling mempelajari gaya hidup maupun pemikiran. Definisi ini lebih mengarah pada 
tujuan pengunjung/atau wisatawan mengunjungi wisata budaya lebih pada untuk memahami hakikat dan membandingkannya dengan kondisi budaya yang dimilikinya sebagai sebuah pemahaman baru, tentunya disamping adanya nilai estetika yang terkandung di dalamnya.

Wisata budaya di Desa Wisata Tapak Tilas Sultan Agung dan Desa Wisata Songgo Langit sangatlah banyak dan memiliki potensi besar jika dikembangan secara baik. Desa Wisata Tapak Tilas Sultan Agung memiliki banyak potensi wisata budaya yang unggulWisata Budaya, Karawitan Ngudiwiromo, Kethoprak Mudo Budoyo, Seni Tari Lestari Budaya, Jathilan Mudo Esthi Tomo, Wayang Kulit Ngesti Budoyo, Gejok lesung Laras budoyo, Sholawat Nabi. Terdapat juga wisata sejarah dan benda kuno yang merupakan koleksi salah satu pengelola desa wisata. Potensi Desa Wisata ini dilakukan untuk melihat keseluruhan potensi yang dimiliki oleh Desa Wisata, baik yang telah dilakukan (potensi nyata) maupun potensi yang masih tersembunyi dan membutuhkan penggalian potensi. Beberapa potensi yang saat ini sedang dikembangkan meliputi:

Sanggar Ngesti Budoyo Songgo Langit. Wisata di Songgo Langit yang menarik dan unggul adalah kesenian yang tergabung dalam Sanggar Ngesti Budoyo, yang didalamnya terdapat Kesenian Wayang Wong, Rasulan, Wiwitan, Sholawat Maulid Nabi, dan lainnya. Wayang Wong ini merupakan suatu pertunjukan teater yang di lakukan sekelompok orang yang menceritakan cerita pewayangan. Wayang wong merupakan suatu perpaduan seni drama, tari dan cerita pewayangan yang di kemas menjadi satu dalam suatu pertunjukan wayang wong. Dalam pementasan wayang wong modern biasanya menggunakan visualisasi panggung yang sesuai dengan cerita agar cerita yang yang di sampailkan dapat mudah tersampaikan kepada para penonton.

Potensi lain adalah upacara adat yang masih dipegang terguh oleh masyarakat, seperti: lamaran, tukon dari pengantin putra, siraman, upacara tradisi pernikahan, sungkeman, kacar kucur, sumpetan, ruwatan, genduri, mitoni, brokohan, puputan, selapanan, ngguwangi, panjang ilang, natah suwunan, pasang tumbal rumah, nglangse, ruwahan, gumbrekan, wiwitan, deselan, bersih dusun, dan kataman.

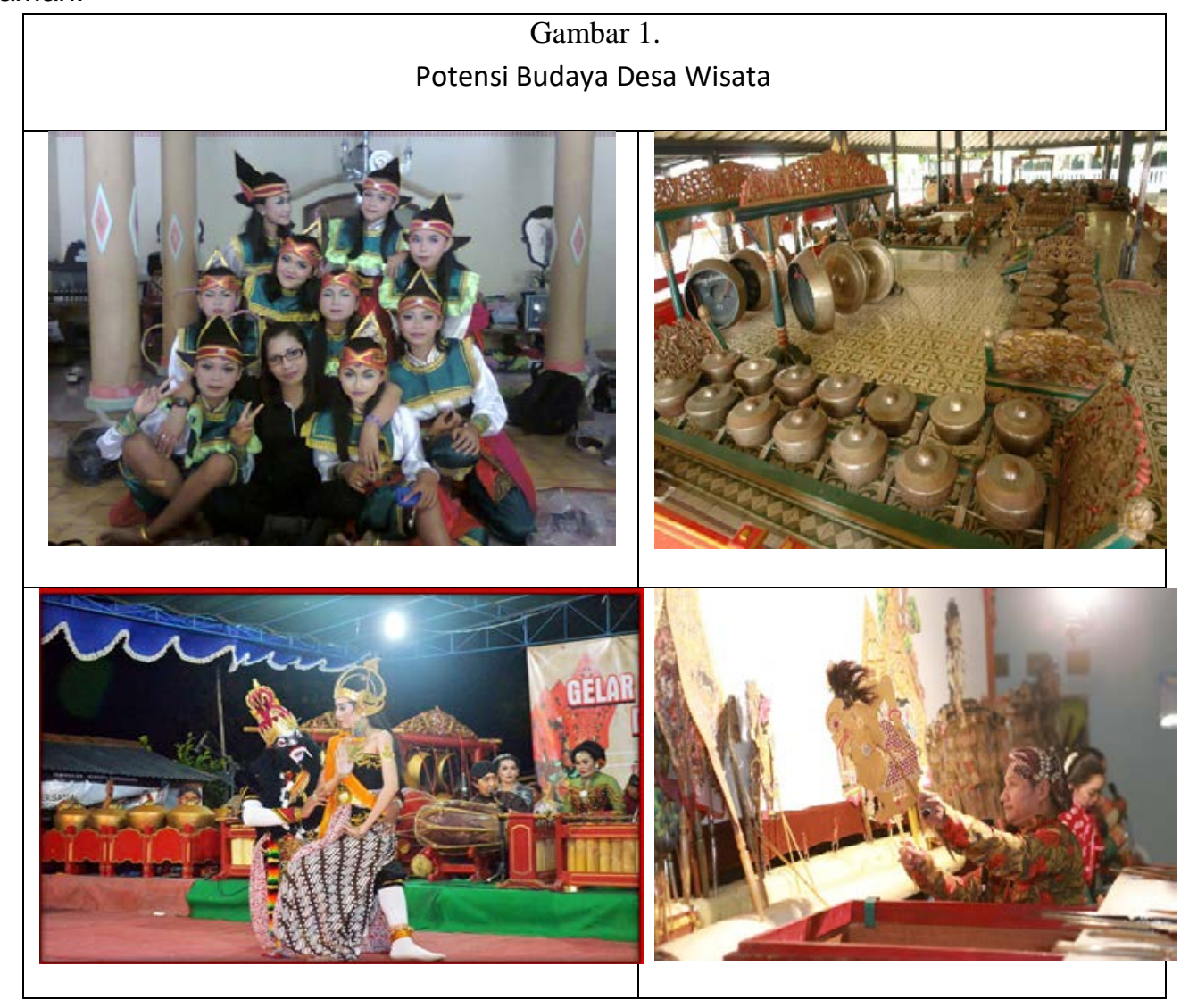




\section{B. Pengembangan Desa Wisata}

Strategi pengembangan wisata dilakukan setelah adanya hasil potensi desa wisata yang hendak dikembangkan. Strategi pengembangan wisata tersebut meliputi:

\section{Penguatan Kelembagaan}

Manajemen Kelembagaan dan manajemen pengelolaan desa wisata ini menjadi sangat penting, mengingat kelembagaan dan manajemen pengelolaan desa wisata merupakan kunci sukses pengembangan desa wisata. Kelembagaan Kepariwisataan adalah kesatuan unsur beserta mitranya yang dikembangkan secara terorganisasi, meliputi Pemerintah Desa, pelaku usaha, dan masyarakat, regulasi dan mekanisme operasional, yang secara berkesinambungan guna menghasilkan perubahan ke arah pencapaian tujuan di bidang Kepariwisataan. Pelatihan ini bertujuan agar pengelola Desa Wisata memahami manajemen kelembagaan kepariwisataan, baik struktur oorganisasi dengan segala kewenangannya dan tentunya sumber daya manusia pengelola desa wisata yang regeneratif dengan pendekatan Community Based Tourism (CBT).

Pengelola Desa wisata yang tumbuh tanpa proses pendidikan pariwisata berbasis wisata modern (kekinian) tentu memiliki banyak kendala dalam pelaksanaanya, namun pemahaman pengelolaan yang baik tersebut dapat dilakukan seiring perjalanan desa wisata yang ada, justru yang menjadi kemenarikan adalah pengelola desa wisata melakukan dengan rutinitas yang berkelanjutan, ikhlas berjuang sekaligus mempertahankan budaya yang dilaksanakan hingga kini. Namun untuk menjadi desa wisata yang maju dan mandiri, tentu membutuhkan manajemen pengelolaan yang baik sesuai dengan minat pengunjung, misalnya pentingnya kelembagaan yang berkaitan dengan promosi desa wisata (hubungan masyarakat), kepemanduan yang baik, pelayanan prima desa wisata, dan lainnya. Apalagi dalam pengelolaan desa wisata dengan pemberdayaan masyarakat lokal (CBT) tentu membutuhkan energi yang maksimal, pengelola desa wisata secara kelembagaan memiliki fungsi untuk memberdayakan masyarakat lokal dalam pengembangan desa wisata.

CBT merupakan konsep pengembang-an suatu destinasi wisata melalui pemberdayaan masyarakat lokal, dimana masyarakat turut andil dalam perencanaan, pengelolaan, dan pemberiaan suara berupa keputusan dalam pembangunannnya. Ada tiga kegiatan pariwisata yang dapat mendukung konsep CBT yakni penjelajahan (adventure travel), wisata budaya (cultural tourism), ekowisata (ecotourism).

CBT akan melibatkan pula masyarakat dalam proses pembuatan keputusan khususnya terkait dengan perolehan pendapatan, kesempatan kerja, serta pelestarian lingkungan dan budaya asli setempat yang pada akhirnya menumbuhkan jati diri dan rasa bangga dari penduduk setempat yang tumbuh akibat peningkatan kegiatan pariwisata. Konsep CBT juga merupakan implementasi ekonomi kerakyatan di sektor riil, yang langsung dilaksanakan dan dinikmati oleh masyarakat sendiri. Pengelola desa wisata dan masyarakat berperan aktif dalam kegiatan pengembangan desa wisata dari mulai perencanaan, implementasi, monitoring dan evaluasi. Hasil kegiatan desa wisata sebanyak mungkin dinikmati oleh masyarakat setempat.

\section{Fasilitasi Pendirian Perkumpulan Sanggar Budaya}

Pengembangan Seni dan budaya di Desa Wisata Tapak Tilas Sultan Agung danDesa Wisata Songgo Langit sangatlah kuat. Di Desa Wisata Tapak Tilas Sultan Agungberdiri Sanggar Lestari Budaya yang berada di Pedukuhan Cempluk, Desa Mangunan.Sanggar Lestari Budaya ini memiliki berbagai kesenian, yaitu:
a. Kerawitan Ngudi wiromo tahun 1980
b. Gejog lesung Setyo Budoyo tahun 1980
c. Kethoprak Mudo Budoyo tanggal 26 juni 1994
d. Sanggar tari Lestari Budoyo tanggal 15 Juni 2004
e. Wayang kulit Ngesti Budoyo tahun 19801
f. Jathilan Klasik Mudo Esthi Tomo 17 Juni 2004 
g. Jathilan Kreasi Putro Mudo Esthi Tomo 2 Mei 2012

h. Sholawat Nabi tahun 1960

i. Campursari/ Elektun Cinta Nada 28 Oktober 2012

j. Hadroh Al Ittihad tahun 2004

Sementara di Desa Wisata Songgo Langit berdiri Sanggar Ngesti Budoyo dengan berbagai kesenian, meliputi: Kesenian Wayang Wong, Rasulan, Wiwitan, Sholawat Maulid Nabi, dan lainnya. Wayang Wong ini merupakan suatu pertunjukan teater yang di lakukan sekelompok orang yang menceritakan cerita pewayangan. Wayang wong merupakan suatu perpaduan seni drama, tari dan cerita pewayangan yang di kemas menjadi satu dalam suatu pertunjukan wayang wong.

Untuk melakukan legalisasi Sanggar Lestari Budaya dan Sanggar Ngesti Budoyo dibuatlah akta notaris Perkumpulan Sanggar Lestari Budaya dan Perkumpulan Sanggar Lestari Budaya agar dalam beraktivitas memiliki keabsahan dan dilindungi oleh Peraturan Perundang-undangan yang berlaku. Akta Notaris ini kemudian di daftarkan ke Kemenkumham, sehingga kedepan Perkumpulan Sanggar Lestari Budaya dan Perkumpulan Sanggar Lestari Budaya diakui keberadaannya oleh Kemenkumham Republik Indonesia.

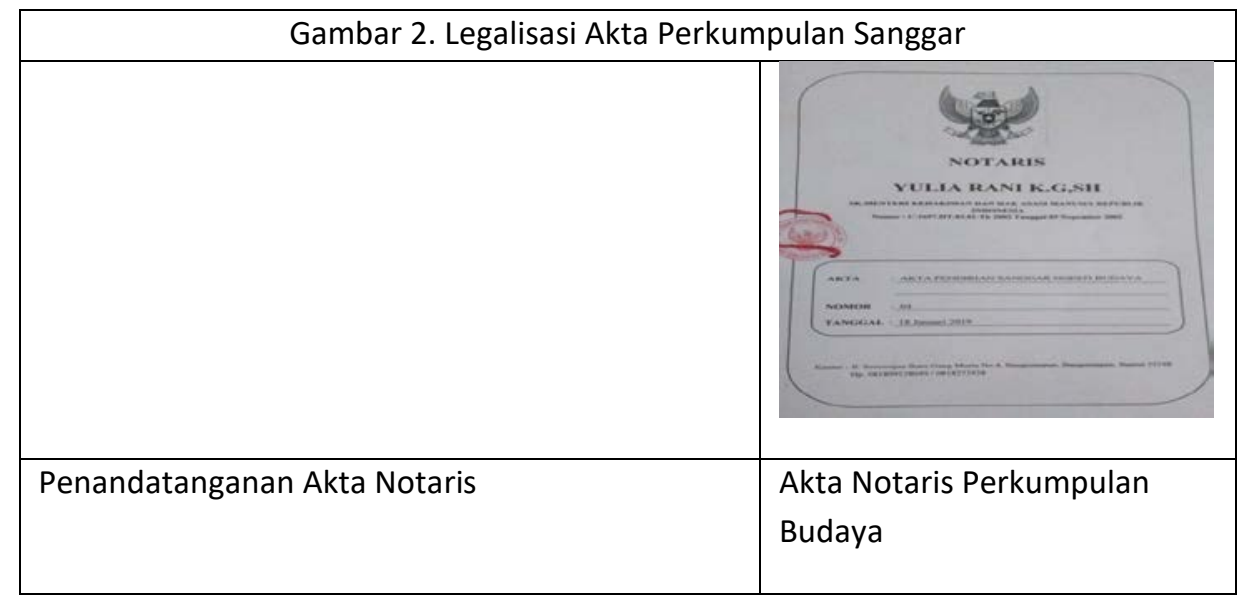

\section{Pelatihan Seni Tari dan Wayang Wong}

Pelatihan ini pandu oleh penari dari Dusun Cempluk sendiri, pelatihan ini untuk mengembangkan wayang wong dan seni tari. Pelatihan Wayang Wong ini diharapkan melahirkan suatu pertunjukan teater yang mampu ditampilkan dengan suasana kekinian dan dengan tema yang dapat diterima segala usia. Sementara Seni tari mengembangan model dan cerita baru bertemakan "nitik siti arum".

\section{Pelatihan Inovasi Pengembangan Wisata Budaya}

Pelatihan inovasi yang dilakukan adalah pelatihan yang berkaitan dengan ruang lingkup pariwisata (pelatihan kepariwisataan) baik bersifat regulatif, manajemen tata kelola, maupun komunikasi pemasaran (Hendrie dan Janianton, 2002, 109). Materi-materi pelatihan yang disampaikan mengambil beberapa kasus dan best practice pengelolaan desa wisata, sehingga peserta pelatihan akan memperoleh gambaran-gambaran kasus dan strategi yang seharusnya dilakukan. Selain itu, juga sharing pengalaman merupakan syarat untuk dapat meningkatkan kreativitas dan inovasi masyarakat dan menjadi penentu pelaksanaan kegiatan dalam menciptakan masyarakat yang mandiri kompetitif berdaya saing (Kesi, 2011:25).

Metode pelatihan dengan diskusi informal bertujuan untuk mendorong partisipasi dan perhatian peserta yang lebih intens (Bevaola dan Hempri, 2015: 21).

Inovasi pengembangan wisata budaya sangatlah penting, bahkan menjadi aspek penting dalam sebuah desa wisata untuk mencapai tujuan. Hal ini dikarenakan keadaan atau kondisi lingkungan 
yang terus mengalami perubahan, sehingga menuntut penyesuaian yang kontinyu atau terusmenerus. Harapannya agar mampu bersaing merebut pasar wisatawan potensial. Penyelenggara pariwisata berlomba-lomba memberikan produk terbaik kepada para wisatawan, menonjolkan daya tarik dari masing-masing produk yang dimiliki.Keunggulan bersaing dikontrol dan dievaluasi secara ketat dan kreatif. Para penyelenggara kegiatan pariwisata tidak segan-segan mengeluarkan investasi dalam jumlah besar untuk memenangkan pasar wisatawan.

Dengan adanya inovasi produk budaya terutama seni tari, kethoprak, wayang wong bertujuan agar tetap diminati kalangan generasi selanjutnya, terutama generasi muda. Langkah yang dilakukan adalah melakukan pengembangan-pengembangan model budaya yang menjadi sasaran wisatawan.

\section{Pemaketan Wisata Budaya}

Pemaketan wisata ini dilakukan dalam bentuk program-program wisata yang lebih terencana dan tersistem. Pemaketan ini menggabungan beberapa kegiatan menjadi satu kegiatan, dalam pemaketan ini digabungkan wisata budaya, wisata alam, outbound, wisata edukasi wayang, dan lainnya. Dalam pemakaten ini sudah ada biaya yang ditawarkan desa wisata terhadap pengunjung dengan konsep live in (menyatu dengan aktivitas masyarakat) maupun one day. FGD Pemaketan ini dipandu oleh Tim Pengabdi.

Gambar 3.

FGD Pemaketan Wisata

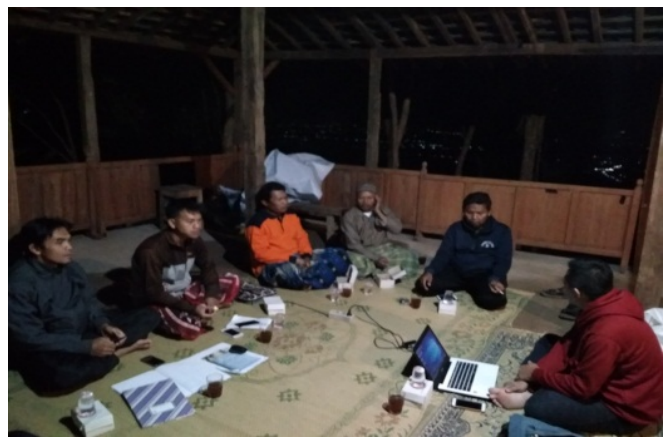

\section{Pementasan Seni dan Budaya}

Pengembangan wisata budaya yang paling akhir adalah pementasan dan promosi, pemetasan biasanya dilakukan bersamaan dengan agenda dusun atau desa atau berdasarkan permintaan pengujung/ wisatawan.

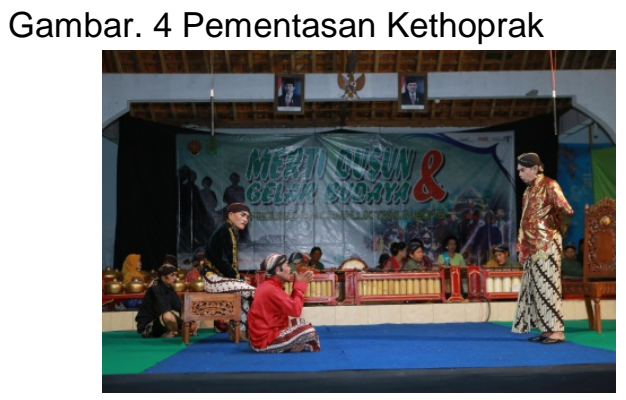

\section{PENUTUP}

Wisata Budaya di Desa Wisata Songgo Langit yang menarik dan unggul adalah kesenian yang tergabung dalam Sanggar Ngesti Budoyo, yang didalamnya terdapat Kesenian Wayang Wong, Rasulan, Wiwitan, Sholawat Maulid Nabi, dan lainnya. Wayang Wong ini merupakan suatu pertunjukan teater yang di lakukan sekelompok orang yang menceritakan cerita pewayangan. Wayang 
wong merupakan suatu perpaduan seni drama, tari dan cerita pewayangan yang di kemas menjadi satu dalam suatu pertunjukan wayang wong. Dalam pementasan wayang wong modern biasanya menggunakan visualisasi panggung yang sesuai dengan cerita agar cerita yang yang di sampailkan dapat mudah tersampaikan kepada para penonton. Potensi Desa Wisata Tapak Tilas Sultan Agung tergabung kedalam Sanggar Lestari Budaya, yang meliputi: Sendra Tari, Karawitan Ngudiwiromo, Kethoprak Mudo Budoyo, Seni Tari Lestari Budaya, Jathilan Mudo Esthi Tomo, Wayang Kulit Ngesti Budoyo, Gejok lesung Laras budoyo, Sholawat Nabi, Hadroh Al Ittihad.

Program pengembangan yang dilakukan, meliputi: legalisasi perkumpulan dalam bentuk sanggar seni. Untuk melakukan legalisasi Sanggar Lestari Budaya dan Sanggar Ngesti Budoyo dibuatlah akta notaris Perkumpulan Sanggar Lestari Budaya dan Perkumpulan Sanggar Lestari Budaya agar dalam beraktivitas memiliki keabsahan dan dilindungi oleh Peraturan Perundangundangan yang berlaku. Akta Notaris ini kemudian di daftarkan ke Kemenkumham, sehingga kedepan Perkumpulan Sanggar Lestari Budaya dan Perkumpulan Sanggar Lestari Budaya diakui keberadaannya oleh Kemenkumham Republik Indonesia. Program lainnya adalah pelatihan wayang wong, wayang kulit, dan Sendra Tari, pelatihan inovasi pengembangan seni budaya, hingga pementasan pada acara tertentu. Program ini diarahkan dalam pementasan wayang wong, wayang kulit, dan sendra tari sebagai wisata budaya mampu memberikan ciri khas kearifan lokal dan modernisasi seni dan budaya, sehingga setiap pementasan dapat memberikan edukasi bagi semua usia.

\section{Ucapan Terima Kasih}

Pada kesempatan ini, kami mengucapkan terimakasih kepada:

1. Kementerian Riset, Teknologi dan Pendidikan Tinggi Republik Indonesia, dengan skema Program Pengembangan Desa Mitra (PPDM) atas dukungan program dan anggaran yang diberikan.

2. Universitas Muhammadiyah Yogyakarta

3. Pemerintah Desa Mangunan, Dlingo, Bantul.

4. Kepala Dusun Cempluk, Dusun Sukarame Desa Mangunan, Dlingo, Bantul

5. Pengelola Desa Wisata Tapak Tilas Sultan Agung dan Pengelola Desa Wisata Songgo Langit.

\section{REFERENCES}

Eko Murdiyanto, dalam "Partisipasi Masyarakat Dalam Pengembangan Desa WisataKaranggeneng, Purwobinangun, Pakem, Sleman, Jurnal Sepa Vol. 7 No.2 Februari 2011.

Juliantara, Dadang., (2003), Pembaharuan Desa, Bertumpu Pada Angka Terbawah, Lappera Pustaka Utama, Yogyakarta.

Kusumasari, Bevaola, dan Hempri Suyatna,(2015) dalam "Peningkatan Kapabilitas Pemasaran Pascabencana Bagi Perempuan Hunian Tetap Pager Jurang, Sleman, Yogyakarta", Jurnal Indonesian Journal of Community Engagement Vol. 01. No. 01.

Nafila, O. (2013). Peran Komuninas Kreatif dalam Pengembangan Pariwisata Budaya di Situs Megalithikum Gunung Padang. Jurnal Perencanaan Wilayah dan Kota, Vol. 24, No. 1, April 2013.

Widjajanti, Kesi, (2011) dalam "Model Pemberdayaan Masyarakat", Jurnal Ekonomi Pembangunan Volume 12, Nomor 1. 